Citar: Climent Serrano, S 2019 Effects of economic variables on NPLs depending on the economic cycle. Empirical Economics. 56 (1) 325-340 DOI.

https://doi.org/10.1007/s00181-017-1362-y

Effects of economic variables on NPLs depending on the economic cycle

Salvador Climent-Serrano

Department of Financial and Actuarial Economics

Faculty of Economics

University of Valencia

Campus Els Tarongers

46022 - Valencia

e-mail: Salvador.climent@uv.es

Phone 0034963828689

orcid.org/0000-0002-5945-8900

The author acknowledges the valuable comments and suggestions made by the anonymous referees of the review. The author wishes to thank the support of the Cátedra de Finanzas Internacionales-Banco Santander. 


\title{
Effects of economic variables on NPLs depending on the economic cycle
}

\begin{abstract}
Late payments are a major problem for Spanish banks. This paper studies as determinants of loan delinquency: unemployment, interest rates, inflation, housing prices, leverage, bad debt coverage and solvency, which were the main problems facing the Spanish economy between 2004 and 2015, and also examines these determinants in periods of growth and recession. The results show that the price of housing, bad debt coverage, interest rates and solvency are the variables with the greatest impact on NPLs. Furthermore, differences exist in the behaviour of variables during periods of growth compared with periods of recession. Inertia of the dependent variable has also been detected.
\end{abstract}

Keywords: loan default, banks, unemployment, leverage, housing prices

JEL classification: G21, M41 


\section{Introduction}

In the period 2004-2008, the Spanish financial system grew at a very fast rate and enjoyed high profits. However, in 2009 the cycle changed and in six years, according to the Bank of Spain, impairment losses amounted to 265.5 billion euros, which is more than $25 \%$ of Spanish GDP. This situation forced the Spanish authorities to request financial aid from the European Commission worth up to 100 billion euros in 2012 (European Commission, 2012).

State aid requested by Spanish banks exceeds 60 billion euros (Climent 2013), 25 billion of which, in 2013 the FROB already considered irrecoverable (FROB 2013). Traditional savings banks have disappeared because they have been absorbed, nationalized or merged and all have been converted into commercial banks (Climent and Pavia 2014, 2015b). Therefore, many towns with small populations have been left without financial services.

In terms of RRHH, between 2010 and 2015, 13,083 branches closed, $29.57 \%$ of the total that existed in 2009 (BdEc 2017). In the last six years, 75,347 jobs have been destroyed, amounting to $27.07 \%$ (BdEc 2017), further aggravating the problem of unemployment in the Spanish economy.

One of the main causes of the events described in the preceding paragraphs is the high level of non-performing loans (NPLs) of Spanish credit institutions. NPLs in this period were the highest recorded by the Bank of Spain, with a maximum of $13.53 \%$ in January 2014. However, these same banks, in the period 2004 to 2007, enjoyed the lowest recorded delinquency rates, less than $1 \%$. This big difference and the events discussed above are sufficiently important reasons for studying the relatively short periods from 2004 to 2009 and from 2010 to 2015. 
The factors that determine bad debts are used to predict future events, especially given the widespread use of stress tests in the banking sector. Therefore, it is important to know how these determinants affect NPLs in each of the two sub-periods, because if there are differences between the results obtained during periods of growth compared with recessions, these differences should be applied to the estimates.

In light of the foregoing, this work has two objectives. Firstly, we will investigate how the main problems suffered by the Spanish economy and the credit institutions have affected loan delinquency rates. To do this, we will study the impact that unemployment levels, interest rates, inflation, the price of housing, leverage, bad debt coverage and solvency have had on loan delinquency in the Spanish credit institutions. Secondly, we will determine if the effect of these factors in periods of economic growth is different compared to recession periods.

New contributions to the literature are made in relation to these two objectives. First, the effects of the main problems suffered by the Spanish economy, and the consequences for NPLs, are considered. Furthermore, two stages (growth and recession) are studied independently, investigating whether a structural break took place. The effect and strength of each of these factors in each of the periods as a determinant of loan delinquency are studied. In addition, a new explanatory variable is included-NPL coverage - that is to say, the ratio calculated as the provision for credit losses divided by the total outstanding loan balance.

Through these two new contributions, techniques will be obtained that serve to predict payment delinquency, in both growth and crisis periods. To do this, we construct an econometric model with a sample period from 2004 to 2015 and two more models with sub-samples from 2004 to 2009 and 2010 to 2015. 
Their use will improve the techniques used in the stress test based on different types of scenarios, because for each type of scenario the impact of economic factors (explanatory variables) will be different, not only because of the change in the value of the variable, but also due to the force that acts on the dependent variable, in this case the nonperforming loans.

The main results obtained in the investigation indicate that the behaviour of the determinants is different in times of economic growth compared with recession periods. Therefore, an increase in the unemployment rate of the same amount does not have the same effect on NPLs when the economy is growing as it does when it is in recession. The same goes for the price of housing, the own funds of credit institutions, leverage, interest rates, inflation, NPL coverage and the inertia of loan delinquency.

\subsection{Justification for the choice of Spain and overview of loan delinquency in Europe}

In the early years of the $21^{\text {st }}$ century, NPLs in most credit institutions around the world remained stable. However, the global financial crisis of 2007 to 2008 affected the quality of loans, but in different ways in each geographical area or country. In the case of Spain, according to Ontiveros and Berges (2010), the impact was delayed by more than a year compared with other countries.

The same factors can affect each country differently. For example, Beck, Jakubik and Piloiu (2013) argue that factors such as the depreciation of the exchange rate produces an increase in NPLs in countries with a high number of foreign currency loans. For example, the depreciation of local currencies in Central, Eastern and Southeastern Europe against the Swiss franc and, to a lesser extent, the Euro, negatively affected the quality of assets in Poland, Hungary and Croatia. The researchers also claim that a decrease in share prices will more negatively affect the quality of bank assets in countries with large stock 
markets. Finally, they indicate that the effect of the same variable - GDP-on loan delinquency is different in various European countries. For example, the effect of GDP on NPLs in the Baltic countries like Latvia is much greater compared to countries such as Germany.

Legislation on mortgage loans also affects different countries differently. For example, a fall in the value of collateral for housing loans will affect loan delinquency differently in countries where mortgage loans legally allow dation in payment (property given in payment of a debt to discharge the debt in full), compared to countries such as Spain where mortgage guarantees extend to all property and personal rights of the holders of the mortgage.

Another factor is how monetary policy is implemented. In the case of Spain, the expansionary monetary policy conducted by the ECB in the early years of the $21^{\text {st }}$ century was counterproductive in the overheated economy in which Spain found itself. This situation further stimulated the housing bubble, which was one of the determinants of the Spanish crisis. However, in other countries one of the main problems was the assets of sub-prime mortgages, a situation that did not affect Spain.

Another of the peculiarities of the Spanish financial system is the incorporation of the generic provisions in 2002. For this reason, the impairment losses depend on various factors, in addition to loan delinquency.

Figure 1 shows the evolution of loan delinquency in 2006 and 2012 and the disparity in the evolution of the same in EU countries, of which a great majority belong to the Euro area with a common monetary policy. 
Figure 1. NPLs of EU countries

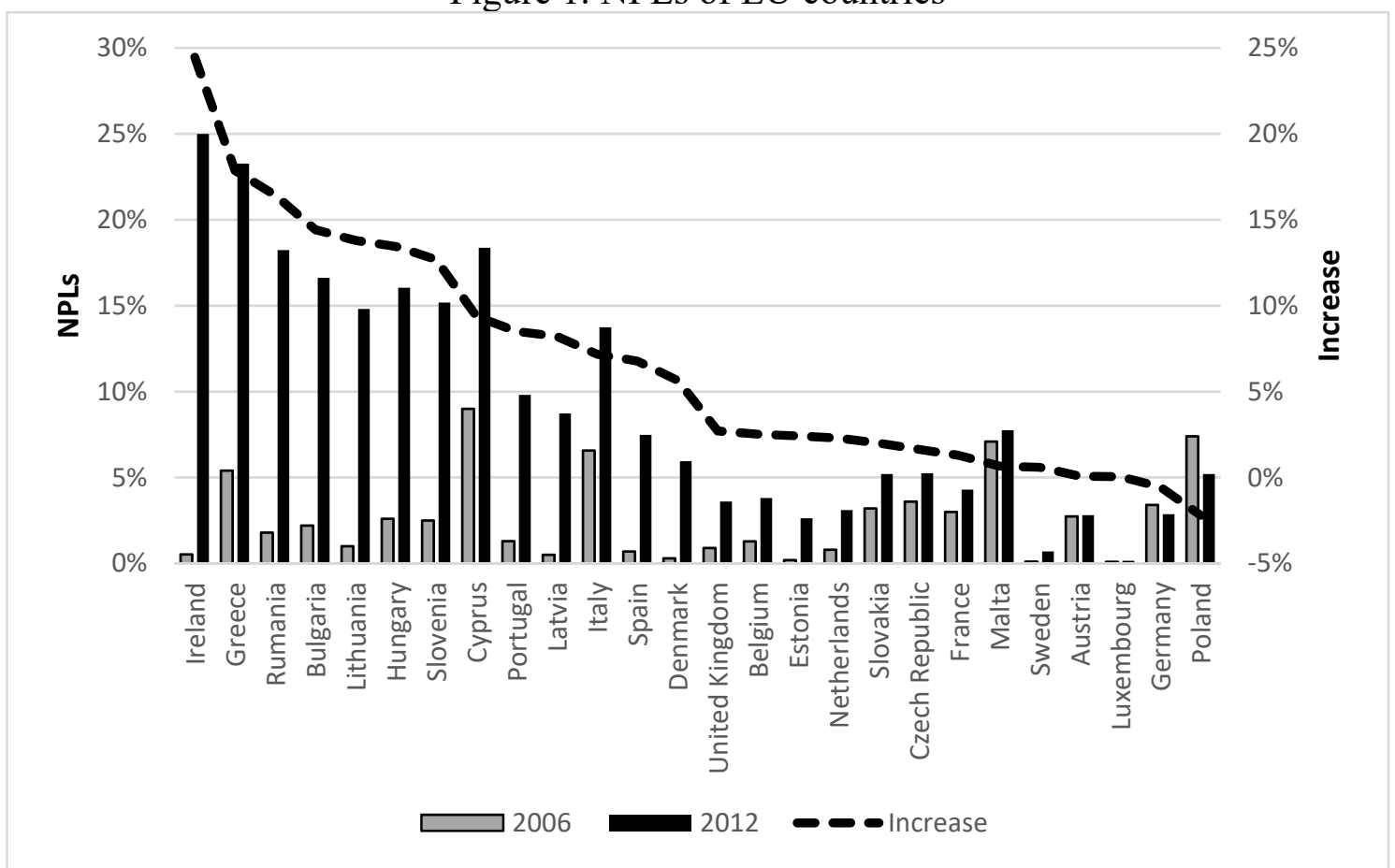

Source: compiled from data from the World Bank-2016

The rest of the paper is organized as follows. Section 2 describes the background to loan delinquency, the selection of variables and the objectives of the research. Section 3 describes the data and the econometric methodology used. Section 4 presents the results obtained and the analysis. Section 5 concludes.

\section{Background}

Loan delinquency and its determinants is a subject that has been widely studied in the empirical literature. Very common in these studies are the relationships of variables related to economic growth, such as GDP or the unemployment rate, and asset quality. The study of NPLs increased in importance thanks to Demirgüç-Kunt (1989), Whalen (1991) and Barr and Siems (1994), for whom bank failures were associated with increases in loan delinquency. 
One of the seminal works on Spain is that of Freixas, Hevia and Inurrieta (1994) in which the authors examine how economic cycles affect NPLs by increasing the volume of loans. They use the aggregate data of bank defaults offered by the Bank of Spain, and create an econometric model adapted from corporate bankruptcies. They conclude that economic growth, inflation, expectations of economic activity, debt levels, monetary policy, wage growth and real interest rates are macroeconomic variables that explain loan delinquency.

Salas and Saurina (2002) use the Arellano-Bond model with panel data to compare the determinants of the delinquency levels of Spanish banks and savings banks in the period 1985-1997. Using macroeconomic variables and internal variables, they find that the variables that explain credit risk are the GDP growth rate, debt levels, credit growth, inefficiency, portfolio composition, size, net interest margin, capital ratio and market power.

Other authors who have studied the determinants of NPLs in Spain are Fernández de Lis et al. (2000), Delgado and Saurina (2004), González and Díez (2010), Jiménez, López and Saurina (2013), Climent (2013) and Climent and Pavía (2015a).

With regard to NPL research focused on other European countries, Podpiera and Weill (2008) study the causality between NPLs and profitability in order to examine whether any of these factors is an important determinant of bank failures. They use Arellano and Bond's General Moment Model in a panel of Czech banks between 1994 and 2005. Their results support the hypothesis of bad management, whereby a deterioration in profitability precedes the increase in NPLs. Foos, Norden and Weber (2010) investigate whether loan growth affected the riskiness of individual banks in Canada, Japan, and 13 European countries between 1997 and 2007. They test three hypotheses on the relationship between abnormal loan growth and asset risk, bank profitability, and bank solvency. Their results 
show that loan growth leads to an increase in loan loss provisions during the subsequent three years, a decrease in interest income and a decline in capital ratios. Festić et al. (2011) use the fixed effects and random effects method with panel data to examine rapid credit growth in Central and Eastern Europe. Their conclusions support the hypothesis that credit growth and the amount of financing available can damage the profitability of credit institutions by the increase in NPLs, probably due to the overheating of the economies of the five new member states from Central and Eastern Europe.

Turning to Italy, the paper of Magri and Pico (2011) evaluates mortgages in Italian banks between 2000 and 2007 by an OLS regression. They conclude that a $1 \%$ increase in the probability of default is associated with an increase of 21 basis points in mortgage interest rates.

In the Greek banking sector, Louzis, Vouldis and Metaxas (2012) look at NPLs using the dynamic panel data method and show that, for all loan categories, Greek NPLs can be explained mainly by macroeconomic variables (GDP, unemployment, interest rates, public debt) and management quality. Differences in the quantitative impact of macroeconomic factors among loan categories are evident, with non-performing mortgages being the least responsive to changes in macroeconomic conditions. Vouldis and Louzis (2017) conduct a new study on Greek banks with regard to NPLs.

At the international level, Berger and DeYoung (1997) employ Granger causality techniques to test whether profitability in banks pre-dates loan quality, whether loan quality pre-dates profitability, or both. To this end, they use data from cross-sectional series of data on non-performing loans, profitability, capital ratios and other variables for commercial banks in the United States between 1985 and 1994. More recently, Brent et 
al. (2011) use panel data with a fixed effects model to examine data on mortgage late payment rates in the USA for 2004 to 2009.

Another study on the US market, that of Demyanyk and Van Hemert (2011), uses loan level panel data to analyse the quality of subprime mortgage loans, examining the characteristics of the loan and macroeconomic conditions. They find that the quality of loans deteriorated for six consecutive years before the crisis, providing evidence that the rise and fall of the subprime mortgage market follows a classic lending boom-bust scenario in which unsustainable growth leads to the collapse of the market. They also say that problems were masked by high housing price appreciation between 2003 and 2005 .

Other works on NPLs for countries around the world include Ghosh (2005) on Indian banks, Asmild and Matthews (2012) on China and Dell'Ariccia, Igan and Leaven (2012), Crook and Banasik (2012), Ramcharan and Crowe (2013) and Sarmiento (2012) on the USA.

\section{Data and econometric methodology}

\subsection{Variables description and dataset}

As seen in the literature review, the diversity of variables used to determine NPLs is wide, comprising macroeconomic and microeconomic variables, internal variables, assets, equity and balance sheet management.

However, as stated above, the main objective of this study is not to determine the factors which cause loan delinquency but to research how the main problems suffered by the Spanish economy have affected NPLs, and especially to discover if this behaviour is the same in times of crisis as in growth periods. To do this, the most important factors that have influenced the Spanish economy and their impact on loan delinquency will be 
assessed for the period 2004 to 2015 . There was a period of great economic growth between 2004 and 2009 and a crisis period from 2010 to 2015 .

The study focuses on seven explanatory variables. There are four external variables of which three are macroeconomic: unemployment, HICP and interest rates, and one microeconomic: the price of housing. The three internal variables are: leverage, solvency and NPL coverage.

The choice of these variables is motivated by the great problems that have affected the Spanish economy. The high rate of unemployment, the housing bubble, the excessive credit growth of commercial and savings banks, and the lack of self-financing have necessitated an injection of public funds into major Spanish banks.

The database used for the calculation of NPLs, own funds, NPL coverage and leverage has been constructed from the annual accounts and reports of the credit institutions that make up the sample. The credit institutions in the database account for $99 \%$ of all banks, credit unions and Spanish savings banks.

The expected results and the construction of the variables used in this research by the authors in the review of the literature now follow.

The dependent variable is NPLs, created by the ratio of NPLs of customers compared to the total loans to customers.

The model includes seven explanatory variables. The first is the unemployment rate, calculated as the rate of annual change in the unemployment rate. The data is obtained from the $\mathrm{EPA}^{1}$ published by the $\mathrm{INE}^{2}$. The unemployment rate as a determinant of NPLs

\footnotetext{
${ }^{1}$ Labour Force Survey

2 The National Statistics Institute
} 
is studied by Brent et al. (2011), Magri and Pico (2011), Demyanyk and Van Hemert (2011), Crook and Banasik (2012), Sarmiento (2012), Louzis, Vouldis and Metaxas (2012), Ramcharan and Crowe (2013) and Vouldis and Louzis (2017). All these authors agree that there is a positive correlation between the unemployment rate and NPLs, although in the work of the last two authors the variable is not statistically significant. Moreover, in the study by Dell'Ariccia, Igan and Leaven (2012) the sign and statistical significance vary depending on the various models with different types of borrowers and different kinds of loans.

The next explanatory variable is the interest rate, the 12-month Euribor published by the Bank of Spain. According to Freixas, Hevia and Inurrieta (1994), Delgado and Saurina (2004), Podpiera and Weill (2008), Jiménez, López and Saurina (2013) and Ramcharan and Crowe (2013), an increase in the interest rate contributes to an increase in NPLs. However, for Crook and Banasik (2012), the effect depends on how the variable is included in the model-NPLs will increase if the variable is taken from that year, but if the interest rate is taken with a delay of one year, the effect is the opposite, with decreasing NPLs. Finally, Dell'Ariccia, Igan and Leaven (2012) conclude that reductions in interest rates increase NPLs as a result of relaxing the conditions for granting mortgages, leading to growth in credit and more loan defaults.

In order to capture the effect of inflation, the third explanatory variable is the Harmonised Index of Consumer Prices (HICP). Inflation can affect NPLs in two different ways. Firstly, higher inflation reduces borrowers' real incomes, causing higher NPLs (Us 2017), and secondly, higher inflation nominally appreciates property and reduces the real value of the loans, so it is expected to reduce NPLs. 
Housing prices, determined as the price per square metre of private housing published by the Ministry of Development in hundreds of euros, is the next variable. There are contradictory results in terms of how the price of real property affects NPLs. Whereas in the studies of Demyanyk and Van Hemert (2011), Brent et al. (2011), Crook and Banasik (2012), Dell'Ariccia, Igan and Leaven (2012) and Sarmiento (2012), the increases in the price of housing contribute to lower NPLs, in the works of Esteban and Estrada (2013) and Ramcharan and Crowe (2013) increased housing prices raise NPLs.

Another explanatory variable is that of leverage, calculated as the ratio of loans to customers divided by customer deposits. Leverage is a determinant of NPLs in the studies of Fernández de Lis et al. (2000), Salas and Saurina (2002), Ghosh (2005), Foos, Norden and Weber (2010) and Louzis, Vouldis and Metaxas (2012). All these authors confirm that increased leverage increases NPLs.

The sixth explanatory variable is solvency, the ratio of equity compared to assets. The increase in own funds as a ratio of the assets or risk-weighted assets is a determining factor contributing to the decline in NPLs in Berger and DeYoung (1997), Fernández de Lis et al. (2000), Salas and Saurina (2002), Ghosh (2005), Foos, Norden and Weber (2010) and Vallascas and Keasey (2012). All authors agree that this variable is also statistically significant in all these studies.

Finally, no studies have been found that include the impairment loss ratio in terms of NPLs. Thus, in this case, it is another novelty that is included in the present work.

Table 1 shows the descriptive statistics of the variables studied. 
Table 1. Descriptive Statistics

\begin{tabular}{|l|c|c|c|c|c|c|c|c|}
\hline & NPLs & Unemployment & $\begin{array}{c}\text { Price of } \\
\text { property }\end{array}$ & Leverage & Equity & Inflation & $\begin{array}{c}\text { NPL } \\
\text { coverage }\end{array}$ & $\begin{array}{c}\text { Interest } \\
\text { rates }\end{array}$ \\
\hline Mean & 0.044 & 0.091 & 18.055 & 1.116 & 0.062 & -0.870 & 1.654 & 0.025 \\
\hline Median & 0.025 & -0.026 & 18.430 & 1.044 & 0.059 & -0.032 & 0.999 & 0.023 \\
\hline Maximum & 0.373 & 0.588 & 20.710 & 2.977 & 0.167 & 2.000 & 7.608 & 0.048 \\
\hline Minimum & 0.001 & -0.165 & 14.590 & 0.575 & -0.059 & -11.500 & 0.145 & 0.002 \\
\hline Std. Dev. & 0.053 & 0.233 & 2.069 & 0.310 & 0.025 & 3.016 & 1.348 & 0.014 \\
\hline
\end{tabular}

\subsection{Econometric methodology}

Due to the relatively short time series and the similarities between the analysed credit institutions, panel data techniques are used to analyse and quantify the impact of the macroeconomic and financial variables. This allows us to capture the specific effects and the unobservable differences between credit institutions. Using a panel data approach, one can control for the biases generated by potential heterogeneity and omit problems with the variables that are persistent over time.

First, correlations between the explanatory variable and the dependent variables are analysed to see the relationships between them. The correlations between the explanatory variables are also studied to see possible cases of multicollinearity. Table 2 shows the correlations between all variables.

Table 2. Correlations between the variables

\begin{tabular}{|c|c|c|c|c|c|c|c|c|}
\hline & NPLs & Unemployment & $\begin{array}{l}\text { Price of } \\
\text { property }\end{array}$ & Leverage & Solvency & Inflation & $\begin{array}{c}\text { NPL } \\
\text { coverage }\end{array}$ & $\begin{array}{c}\text { Interest } \\
\text { rates }\end{array}$ \\
\hline NPLs & 1 & & & & & & & \\
\hline $\begin{array}{c}\text { Unemploy } \\
\text { ment }\end{array}$ & $0.160 * * *$ & 1 & & & & & & \\
\hline $\begin{array}{l}\text { Price of } \\
\text { property }\end{array}$ & $-0.417 * * *$ & $0.384 * * *$ & 1 & & & & & \\
\hline Leverage & $-0.153 * * *$ & 0.026 & $0.220 * * *$ & 1 & & & & \\
\hline Solvency & $-0.255 * * *$ & $-0.101 * *$ & $-0.099 * *$ & $-0.178 * * *$ & 1 & & & \\
\hline Inflation & $-0.130 * * *$ & $-0.101 * *$ & -0.060 & -0.040 & 0.047 & 1 & & \\
\hline $\begin{array}{c}\text { NPL } \\
\text { coverage }\end{array}$ & $-0.572 * * *$ & $-0.529 * * *$ & $0.121 * * *$ & 0.033 & $0.182 * * *$ & $0.204 * * *$ & 1 & \\
\hline $\begin{array}{c}\text { Interest } \\
\text { rates }\end{array}$ & $-0.551 * * *$ & 0.041 & $0.806 * * *$ & $0.187 * * *$ & -0.034 & $0.250 * * *$ & $0.338 * * *$ & 1 \\
\hline \multicolumn{9}{|c|}{ Significance level $* * *, * *, * 1 \%, 5 \%$ and $10 \%$ respectively } \\
\hline
\end{tabular}


The problems of multicollinearity are discarded and it is verified that the explanatory variables can be good predictors of loan delinquency. The unit root test has detected seasonality in the unemployment variable, so this variable will be taken in differences. In the other explanatory variables, there are no seasonality problems.

As for the econometric analysis, in a first regression a strong inertia of the dependent variable is detected. As a result, the dynamic panel model used is a two-step Generalized Method of Momentum (GMM) proposed by Arellano and Bond (1991), Arellano and Bover (1995), Blundell and Bond (1998), Bond and Windmeijer (2005) and Cucinelli (2016). The technique is especially suitable for small samples of $\mathrm{T}$ and large $\mathrm{N}$, such as in this work.

The GMM model facilitates the obtention of consistent and unbiased estimates of the relationship between the banks' specific variables and the behaviour of non-performing loans. This methodology helps to alleviate some of the problems of endogeneity if the instruments are not correlated with the variables investigated (Espinoza and Prasad 2010, Said et al. 2013, Kohler et al. 2015). To test for the absence of correlation between the instruments and the error term, the Sargan test is performed.

To verify the linearity or not of the model, two models will be estimated, one with the dependent variable in levels and another one taken with logarithms. To detect the structural change, three regression models will be considered — one with all the years from 2004-2015 and two from each of the two sub-samples, 2004-2009 and 2010-2015, and a coefficient difference test will be performed between the two sub-samples.

All regression models have been estimated using robust standard errors using the White method. There is no multicollinearity between the explanatory variables. The Influence Factor of Variance in all variables is less than 10. 
The models are as follows:

$$
\begin{aligned}
& \mathrm{NPLs}_{i t}=\beta_{1} \mathrm{NPLs}_{i(t-1)}+\beta_{2} \text { Unemployment }_{\text {rate }}{ }_{i t} \\
& +\beta_{3} \text { HIPC }_{i t}+\beta_{4} \text { Rate of interest } i t+\beta_{5} \text { House prices }_{i t}+\beta_{6} \text { Leverage }_{i t} \\
& +\beta_{7} \text { Solvency }_{i t}+\beta_{8} N P L \text { coverage } \text { cit }+\omega_{i t} \\
& \log \mathrm{NPLs}_{i t}=\beta_{1} \log \mathrm{NPLs}_{i(t-1)}+\beta_{2} \text { Unemployment }_{\text {rate }} \text { it } \\
& +\beta_{3} \text { HIPC }_{i t}+\beta_{4} \text { Rate of interest }{ }_{i t}+\beta_{5} \text { House prices }_{i t}+\beta_{6} \text { Leverage }_{i t} \\
& +\beta_{7} \text { Solvency }_{i t}+\beta_{8} \text { NPL coverage } \text { cit }+\omega_{i t}
\end{aligned}
$$

\section{Results and discussion}

Table 3 shows the six econometric models. The dependent variable is the non-performing loans. Three regressions are made with a linear adjustment and three with a logarithmic adjustment. The same table shows the elasticity and the coefficient difference test.

According to the results obtained, the NPLs of Spanish credit institutions in the period studied are better adjusted to a non-linear function, in particular logarithmically. When analyzing the results, it is found that the explanatory variables have a strong influence on the evolution of NPLs. Therefore, in this section we will comment on the results with respect to the first objective of the present work.

First of all, significant inertia of the dependent variable is detected with a coefficient and elasticity of 0.538 . With respect to the explanatory variables, unemployment acts as expected: an increase in the unemployment rate increases NPLs - in this case the elasticity is 0.073 . One of the main factors that has influenced NPLs is the evolution of housing prices. An increase in the price of housing significantly reduces NPLs, since the elasticity of this variable is -3.262 . The increase in leverage, in contrast to the results seen in the review of the literature, reduces NPLs, although the impact is reduced with an elasticity of -0.104 . 
Table 3. Regression models

\begin{tabular}{|c|c|c|c|c|c|c|c|c|c|}
\hline \multicolumn{10}{|c|}{ Dependent variable: Non-performing loans } \\
\hline & \multicolumn{4}{|c|}{ In levels: Linear model } & \multicolumn{5}{|c|}{ In logarithms: Nonlinear model } \\
\hline & $2004-2015$ & 2004-2009 & $2010-2015$ & Difference & $2004-2015$ & Elasticity & 2004-2009 & $2010-2015$ & Difference \\
\hline \multirow{2}{*}{ NPLs $(-1)$} & $0.666^{* * *}$ & 0.577 & $0.481 * * *$ & 0.096 & $0.538 * * *$ & 0.538 & 0.011 & $0.075 * *$ & $-0.062 * * *$ \\
\hline & $(0.006)$ & $(0.616)$ & $(0.018)$ & & $(0.011)$ & & $(0.012)$ & $(0.023)$ & \\
\hline \multirow{2}{*}{ Unemployment } & $0.061 * * *$ & $0.046^{* * *}$ & $0.084 * * *$ & $-0.037 * * *$ & $0.809 * * *$ & 0.073 & $1.727 * * *$ & $0.586^{* * *}$ & $1.144 * * *$ \\
\hline & $(0.001)$ & $(0.010)$ & $(0.004)$ & & $(0.030)$ & & $(0.242)$ & $(0.027)$ & \\
\hline \multirow{2}{*}{$\begin{array}{l}\text { Price of } \\
\text { property }\end{array}$} & $-0.015 * * *$ & $-0.009 * * *$ & $-0.024 * * *$ & $0.015 * * *$ & $-0.181 * * *$ & -3.262 & $-0.177 * * *$ & $-0.300 * * *$ & $0.122 * * *$ \\
\hline & $(0.000)$ & $(0.002)$ & $(0.001)$ & & $(0.004)$ & & $(0.024)$ & $(0.007)$ & \\
\hline \multirow{2}{*}{ Leverage } & $0.014 * * *$ & -0.017 & $0.015 * * *$ & -0.032 & $-0.093 * * *$ & -0.104 & -0.192 & $0.329 * * *$ & $-0.521 * * *$ \\
\hline & -0.001 & $(0.020)$ & $(0.003)$ & & $(0.011)$ & & $(0.207)$ & $(0.033)$ & \\
\hline \multirow{2}{*}{ Solvency } & $-0.753 * * *$ & $-1.153 * * *$ & $-0.448 * * *$ & $-0.705 * * *$ & $-7.348 * * *$ & -0.457 & $-10.032 * *$ & $-5.843 * * *$ & -4.188 \\
\hline & $(0.030)$ & $(0.291)$ & $0.009)$ & & $(0.350)$ & & $(5.021)$ & $(0.555)$ & \\
\hline \multirow{2}{*}{ Inflation } & $-0.001 * * *$ & $-0.002 *$ & $-0.002 * * *$ & 0.001 & $-0.145^{* * *}$ & 0.013 & $-0.082 * * *$ & $-0.018 * * *$ & $-0.064 * * *$ \\
\hline & $(0.000)$ & $(0.001)$ & $(0.000)$ & & $(0.001)$ & & $(0.014)$ & $(0.001)$ & \\
\hline \multirow{2}{*}{ NPL coverage } & $-0.002 * * *$ & -0.001 & $-0.056 * * *$ & $0.054 * * *$ & $-0.405 * * *$ & -0.671 & $-0.354 * * *$ & $-0.842 * * *$ & $0.488 * * *$ \\
\hline & $(0.000)$ & $(0.002$ & $(0.003)$ & & $(0.012)$ & & $(0.040)$ & $(0.021)$ & \\
\hline \multirow{2}{*}{ Interest rates } & $1.231^{* * *}$ & 0.821 & $2.018^{* * *}$ & $-1.198 * *$ & $24.898 * * *$ & 0.627 & $13.432 *$ & $12.009 * * *$ & 1.422 \\
\hline & $(0.045)$ & $(0.521)$ & $(0.076)$ & & $(0.788)$ & & $(04.774)$ & $(0.509)$ & \\
\hline J statistic & 53.067 & 18.474 & 33.690 & & 39.855 & & 6.437 & 30.41 & \\
\hline $\begin{array}{l}\text { Prob (J- } \\
\text { statistic) }\end{array}$ & 0.081 & 0.018 & 0.293 & & 0.432 & & 0.490 & 0.394 & \\
\hline $\begin{array}{c}\text { Instruments } \\
\text { rank }\end{array}$ & 48 & 16 & 38 & & 47 & & 15 & 37 & \\
\hline $\mathrm{N}$ & 381 & 271 & 139 & & 381 & & 271 & 139 & \\
\hline
\end{tabular}

Regarding equity, the higher the solvency level of the banks, the lower the default rate, with a very important effect, since the elasticity of this variable is -0.457 . Inflation influences NPLs according to the second theory presented in the description of the variables, since its increase reduces NPLs - in this case the impact is also moderate with an elasticity of 0.013. An important result is the influence of NPL coverage for loan delinquency (percentage of impairment losses provided as provisions). In this case it is verified that the greater the coverage, the lower the NPLs. In addition, the influence is important since the elasticity is -0.671 . Finally, interest rates also have an important 
impact on loan delinquency. As interest rates rise, non-performing loans rise significantly, with an elasticity of 0.627 .

\subsection{Structural analysis}

In this section we examine the second objective of the work, in particular, if the effect of these factors seen in the previous section is different in growth periods compared to recession periods. According to the results obtained, it can be affirmed that the impact of the same explanatory variable in NPLs is different according to the economic cycle. In the coefficient difference test, five of the seven explanatory variables have been statistically significant when evaluating the difference between the coefficients of the two sub-samples, which cover the growth stage and the recession stage. These variables are: unemployment, housing prices, leverage, inflation and NPL coverage. In addition, the difference in inertia of the dependent variable between the two sub-periods is also statistically significant.

Regarding the differences between these variables, it is verified that the impact of unemployment and inflation is higher in the stages of growth than in the recession stages, while for housing prices, leverage and coverage of the NPLs, the impact is greater in times of growth. As for inertia, this is greater in the periods of recession.

\subsection{Discussion of the results obtained}

In the six models it is shown that some inertia in the NPLs does exist. However, the most important research result obtained is that the magnitude of the impact of the variables on NPLs is not of the same intensity in periods of growth as it is in periods of recession.

The results obtained, along with the economic situation, explain in part the rescue of Spanish credit institutions, which led to an injection of public funds of more than 60 
billion euros. At the same time, these results can be used to allow policy-makers to prevent or mitigate crises. This is because although variables such as unemployment are difficult to control, others such as the evolution of housing prices, the increase in credit (leverage), the types of interest or the regulation of the own funds of credit institutions can be regulated by the political authorities.

The impact of the housing bubble, encouraged by the expansionary monetary policy conducted by the Bank of Spain in an overheated economy such as the Spanish one, was one of the main causes of the increase in loan defaults and, consequently, of the bailout provided to Spanish credit institutions. The decrease in housing prices since 2008, together with the result obtained in the model with a -3.262 elasticity, contributed significantly to the increase in NPLs. This is one of the main causes of the crisis of the Spanish credit institutions. Policy-makers could have mitigated this circumstance by taking measures that would have slowed the housing bubble, which they clearly knew was developing.

A similar situation occurred in the own funds of banks, since supervision was not as diligent as it should have been. Examples of this were the interventions that occurred and the reformulation of the financial statements with the appearance of a large number of bad loans, especially in Spanish savings banks. In this case, policy-makers should have regulated much earlier to avoid some of the crisis, since they were aware of the dangerous financial situation. Thus, the supervising authority (the Bank of Spain) should have initiated policies to strengthen and control own funds much earlier than it did. This is demonstrated by the new rules that have emerged since Basel III.

Another important result is the one obtained in the variable that measures the NPL coverage. In this case, an a priori explanation of this result cannot be given, so it would 
be an interesting topic for further investigation. One of the possible explanations for this result is that the profits are being managed, so that when the percentage of coverage is high, the NPLs grow less than when the percentage is low. Another possible cause could be the impact of the generic provisions implemented in Spain and which depend on other factors such as credit growth and the coverage of same, in addition to NPLs. This variable is one of the most important in the stress tests carried out periodically by the European Banking Authority.

Finally, the results obtained indicate that the effects of the variables that determine NPLs are different in times of recession compared to periods of growth. This observation is important because when policy-makers make their forecasts, this characteristic is not taken into account. For example, in the stress tests, when two or more scenarios are projected, the impact of the variables is the same-what they change are the macroeconomic or microeconomic data or the estimates of the assets and liabilities of credit institutions. Hence, this characteristic must be considered and different parameters for different scenarios must be estimated, thereby lessening the errors in the results of the stress test. Note that sometimes the forecast is very different from reality, such as the

stress test of the European Banking Authority (EBA) confirming the good solvency of Bankia, which was published on 20 July 2011, the same day the Initial Public Offering ended (Climent and Pavia 2015b).

\section{Conclusions}

The Spanish financial system has undergone a profound change, with the financial map of 2013 being substantially different from that of 2010. In just two years, the savings banks, which had $50 \%$ of the market share, disappeared or underwent a profound transformation. All has been motivated in large part by the large allocations to cover NPLs 
that reached record highs with figures above 13\%. However, in the period 2004 to 2007 , the rate of NPLs was extremely low and stable, less than $1 \%$ throughout the period.

This great difference between the two periods is very important for the study of the main determinants of NPLs, especially to see if the effect on them is the same in periods of economic growth and crisis. It is for this reason that this study has researched the effect on NPLs of the main factors of the Spanish crisis, studying the differential effect in two stages - recession and growth.

To this end, an econometric model has been estimated with panel data composed of most of the Spanish credit institutions, representing more than $99 \%$ of the assets of banks, credit unions and savings banks. We have studied the behaviour of the determinants of NPLs and especially if this behaviour is statistically different in times of economic growth compared with times of recession, with the aim of giving the financial system a new tool to predict the effects of leverage (credit growth), unemployment, solvency, the evolution of own funds and the movement of housing prices according to the cycle of the economy, i.e. growth or recession.

One of main results obtained is that the behaviour of the determinants is different in recession periods than in times of growth.

The price of housing is a very important factor affecting NPLs. In addition, the increase in unemployment and in interest rates increases NPLs, while the increase in housing prices, leverage, solvency, inflation and NPL coverage decreases them.

In summary, it is clear that the impact on NPLs by the internal and external variables studied is very important in explaining NPLs. 
In conclusion, it can be said that the results obtained can be helpful in applying preventative measures against loan delinquency by the policy markets. In addition, the results can be used to improve the methodology used in the stress tests to which the credit institutions are periodically subject. In this case, to differentiate the different stages of the economy, it is necessary to apply different intensities with regard to the impacts of the variables affecting NPLs, because the effect on NPLs of these variables is different in times of recession, not only from the change in the variable data, which is logical, but also from the intensity at which NPLs are affected in different economic situations. Therefore, the parameters used in the various stages of the stress test must be different.

\section{References}

Arellano, M. \& Bover, O. (1995) Another look at the instrumental variable estimation of error-components models, Journal of Econometrics 68(1):29-51. https://doi.org/10.1016/0304-4076(94)01642-D

Arellano, M., \& Bond, S. (1991) Some tests of specification for panel data: Monte Carlo evidence and an application to employment equations. The review of economic studies 58(2):277-297. doi: https://doi.org/10.2307/2297968

Asmild, M. \& Matthews, K. (2012) Multi-directional efficiency analysis of efficiency patterns in Chinese banks 1997-2008. European Journal of Operational Research 219 (2):434-441. http://doi.org/10.1016/j.ejor.2012.01.001

Banco de España (2017a) Boletín estadístico. Entidades de crédito. Cuadros complementarios. http://www.bde.es/webbde/es/estadis/infoest/bolest4.html

Banco de España (2017b) Datos de créditos dudosos. http://www.bde.es/webbde/es/estadis/infoest/a0403.pdf, 
Barr, R. S., \& Siems, T. F. (1994) Predicting bank failure using DEA to quantify management quality 94-1. Federal Reserve Bank of Dallas.

Beck, R. Jakubik, P. \& Piloiu, A. (2013) Non-performing loans: What matters in addition to the economic cycle? European Central Bank. Working Paper Series n ${ }^{\circ} 1515$ / February 2013

Berger, A. N. \& DeYoung, R. (1997) Problem loans and cost efficiency in commercial banks. Journal of Banking \& Finance 21(6):849-870. https://doi.org/10.1016/S0378-4266(97)00003-4

Blundell, R. \& S. Bond (1998) Initial conditions and moment restrictions in dynamic panel data models. Journal of Econometrics 87(1):115-143. http://doi.org/10.1016/S0304-4076(98)00009-8

Bond, S. \& F. Windmeijer (2005) Reliable inference for GMM estimators? Finite sample properties of alternative test procedures in linear panel data models. Econometric Reviews 24(1):1-37. http://dx.doi.org/10.1081/ETC-200049126

Brent, W. Kelly, L. Lindsey-Taliefero and D. Price, R. (2011) Determinants of Mortgage Delinquency. Journal of Business and Economics Research 9 (2):27-47. doi: http://dx.doi.org/10.19030/jber.v9i2.1815

Climent Serrano, S. (2012) La caída de las cajas de ahorros españolas. Cuestión de rentabilidad, tamaño y estructura de propiedad. Estudios de Economía Aplicada $30(2): 1-26$.

Climent-Serrano, S \& Pavía JM (2014) Determinantes y diferencias en la rentabilidad de Cajas y Bancos. Revista de economía aplicada 22(65):117-154. 
Climent-Serrano, S \& Pavía JM (2015a) Determinants of profitability in Spanish financial institutions. A comparative study of the entities that needed public funds and those that did not. Journal of Business Economics and Management 16(6):1170-1184. http://dx.doi.org/10.3846/16111699.2013.801881.

Climent-Serrano, S \& Pavía JM. (2015b) BANKIA: ¿Para qué sirven los estados contables y los órganos de control? Estudios de Economía Aplicada 33(1):1-42.

Climent-Serrano, S. (2013) La reestructuración del sistema bancario español tras la crisis y la solvencia de las entidades financieras. Consecuencias para las cajas de ahorros. Revista de Contabilidad Spanish Accounting Review 16 (2):136-146. http://doi.org/10.1016/j.rcsar.2013.07.003

Crook, J. \& Banasik, J. (2012) Forecasting and explaining aggregate consumer credit delinquency behavior. International Journal of Forecasting 28:145-160. http://doi.org/10.1016/j.ijforecast.2010.12.002

Cucinelli, D. (2016) Can speed kill? The cyclical effect of rapid credit growth: evidence from bank lending behavior in Italy. The Journal of Risk Finance 17(5). doi: 10.1108/JRF-03-2016-0035

Delgado, J. \& Saurina, J. (2004) Riesgo de crédito y dotaciones a insolvencias. Un análisis con variables macroeconómicas. Moneda y Crédito 219:11-42.

Dell'Ariccia, G., Igan, D. \& Leaven, L. (2012) Credit booms and lending standards: evidence from the subprime mortgage market. Journal of Money, Credit and Banking 44 (2-3):367-384. doi: 10.1111/j.1538-4616.2011.00491.x 
Demirgüç-Kunt, A. (1989) Deposit-institution failures: a review of empirical literature. Economic Review - Federal Reserve Bank of Cleveland; Cleveland 25(4):2-19.

Demyanyk, Y. \& Van Hemert, O. (2011) Understanding the Subprime Mortgage Crisis. The Review of Financial Studies 24 (6):1847-1880. doi: https://doi.org/10.1093/rfs/hhp033

Espinoza, R.A. \& Prasad, A. (2010) Non-performing loans in the GCC banking system and their macroeconomic effects. IMF Working paper No 10/224.

Esteban Carranza, J. \& Estrada, D. (2013) Identifying the determinants of mortgage default in Colombia between 1997 and 2004. Annals of Finance 9:501-518. DOI: $10.1007 / \mathrm{s} 10436-012-0196-\mathrm{Z}$

European Commission (2012) Eurogroup statement on Spain http://ec.europa.eu/spain/pdf/eurogrupo-espahna-09.06.pdf

Fernández de Lis, S. Martínez, J. \& Saurina, J. (2000) Crédito bancario, morosidad y dotación de provisiones para insolvencias en España. Boletín Económico Banco de España, November:1-10

Festić, M., Kavkler, A., \& Repina, S. (2011) The macroeconomic sources of systemic risk in the banking sectors of five new EU member states. Journal of Banking \& Finance 35(2):310-322. http://doi.org/10.1016/j.jbankfin.2010.08.007

Foos, D. Norden, L. and Weber, M. (2010) Loan growth and riskiness of Banks. Journal of Banking $\quad \& \quad$ Finance $\quad 34: 2929-2940$. http://doi.org/10.1016/j.jbankfin.2010.06.007 
Freixas Dargallo, X., De Hevia Payá, J. \& Inurrieta Beruete, A. (1994) Determinantes macroeconómicos de la morosidad bancaria: un modelo empírico para el caso español. Moneda y Crédito 199:125-156.

Ghosh (2005). Does leverage influence banks' non-performing loans? Evidence from India. Applied Economics Letters 12(15):913-918. http://dx.doi.org/10.1080/13504850500378064

González Pascual, J. and Díez Cebamanos, N. (2010) El crédito y la morosidad en el sistema financiero español. Boletín Económico de ICE 2997:51- 65.

Jimenez, G., Lopez, J.A. \& Saurina, J. (2013) How does competition affect bank risktaking? Journal of $\quad$ Financial Stability 9:185-195. http://doi.org/10.1016/j.jfs.2013.02.004

Kohler, K., Guschanski, A. \& Stockhammer, E. (2015) "How does financial affect functional income distribution? A theoretical clarification and empirical assessment”, Economic Discussion papers 2015-2005, Kingston University London, London.

Louzis, D. P., Vouldis, A. T. \& Metaxas, V. L. (2012) Macroeconomic and bank-specific determinants of non-performing loans in Greece: A comparative study of mortgage, business and consumer loan portfolios. Journal of Banking \& Finance 36(4):1012-1027. http://doi.org/10.1016/j.jbankfin.2011.10.012

Magri, S. \& Pico, R. (2011) The rise of risk-based pricing of mortgage interest rates in Italy. Journal of Banking \& Finance 35(5):1277-1290. http://doi.org/10.1016/j.jbankfin.2010.10.008 
Ontiveros, E., \& Berges, A. (2010) Cajas y bancos: la gestión de la crisis. Economía Exterior 54:27-38.

Podpiera, J. \& Weill, L. (2008) Bad luck or bad management? Emerging banking market experience. Journal of Financial Stability 4:135-148. http://doi.org/10.1016/j.jfs.2008.01.005

Ramcharan, R. \& Crowe, C. (2013) The impact of house prices on consumer credit: evidence from an internet bank. Journal of Money, Credit and Banking 45(6):1085-1115. doi: 10.1111/jmcb.12045

Said, R., Daud, M.M., Radjeman, L.A. \& Ismail, N. (2013) Probing corporate ethical identity of Shari'ah compliant companies. Procedia Economics and Finance 7:230-235. https://doi.org/10.1016/S2212-5671(13)00239-6.

Salas, V. \& Saurina, J. (2002) Credit Risk in Two Institutional Regimes: Spanish Commercial and Savings Banks. Journal of Financial Services Research 22(3):203-224. doi: 10.1023/A:1019781109676

Sarmiento, C. (2012) The role of the economic environment on mortgage defaults during the Great Recession. Applied Financial Economics 22(3):243-250. http://dx.doi.org/10.1080/09603107.2011.613753

Us, V. (2017) A dynamic approach to analysing the effect of the global crisis on nonperforming loans: evidence from the Turkish banking sector. Applied Economics Letters 24(3):186-192. doi: 10.1080/13504851.2016.1176106 
Vallascas, F. \& Keasey, K. (2012) Bank resilience to systemic shocks and the stability of banking systems: Small is beautiful. Journal of International Money and Finance 31(6):1745-1776. http://doi.org/10.1016/j.jimonfin.2012.03.011

Vouldis, A. T. \& Louzis, D. P. (2017) Leading indicators of non-performing loans in Greece: the information content of macro-, micro-and bank-specific variables. Empirical Economics 1-28. doi:10.1007/s00181-017-1247-0

Whalen, G. (1991) A proportional hazards model of bank failure: an examination of its usefulness as an early warning tool. Economic Review - Federal Reserve Bank of Cleveland 27(1):21-30. 